\title{
Stosowanie deliktowych lączników lokalnych do zdarzeń mających miejsce na pokładzie statku morskiego lub powietrznego w unijnym prawie prywatnym międzynarodowym
}

\begin{abstract}
The article is aimed at determining the relevance of the flag state (regarding vessels) and the country of registration (regarding aircrafts) principles for the purpose of the application of territorial connecting factors (the place of the event giving rise to damage (place of acting) and the place where the damage occurred (place of damage)) employed by article 7(2) of the Regulation No 1215/2012 (Brussels I bis Regulation) providing a special jurisdiction rule in matters relating to tort, delict or quasi-delict and by article 4(1) of the Regulation No 864/2007 (Rome II Regulation) specifying the law applicable to a non-contractual obligation arising out of a tort or delict. The flag state and the country of registration principles could be taken into account when circumstances constituting the event giving rise to damage or the damage itself are situated on board of a vessel navigating in or an aircraft flying through the areas outside the sovereignty of any state (in particular the High Seas). The reference to the flag state or the country of registration instead of the sovereignty in order to identify the member state whose courts have jurisdiction pursuant to article 7(2) of the Brussels I bis Regulation or the state whose law is applicable according to article 4(1) of the Rome II Regulation may also be possible in cases when the determination of the place where the event giving rise to damage occurred or where the damage occurred is difficult or even when the competent jurisdiction and the applicable law identified based on the sovereignty over the area where the
\end{abstract}

a) Mgr, asystent w Katedrze Prawa Prywatnego Międzynarodowego, Wydział Prawa i Administracji Uniwersytet Jagielloński. 
vessel navigated or the aircraft flew at the moment when the event giving rise to damage occurred or damage occurred does not materialise the closest connection principle.

Keywords: the place of the event giving rise to damage, place of damage, flag state of the vessel, registration state of the aircraft, Rome II Regulation, Brussels I bis Regulation

\section{Wstęp}

Celem artykułu jest ustalenie, jakie znaczenie ma zasada bandery i zasada państwa rejestracji dla stosowania deliktowych łączników lokalnych ustanowionych w rozporządzeniu $\mathrm{nr} 1215 / 2012^{1}$ oraz w rozporzadzeniu $n r$ 864/20072. Potrzeba uwzględnienia zasady bandery lub zasady państwa rejestracji pojawia się przede wszystkim wtedy, gdy okoliczności stanowiące zdarzenie powodujące szkodę lub szkodę są zlokalizowane na obszarach niepodlegających władztwu żadnego państwa. Sięgnięcie po te zasady może być celowe również wtedy, kiedy dokładne ustalenie, gdzie doszło do zdarzenia powodującego szkodę lub gdzie powstała szkoda, jest utrudnione albo kiedy rozstrzygnięcie o jurysdykcji krajowej lub o prawie właściwym w oparciu o to, które państwo sprawuje władztwo terytorialne nad obszarem, na którym znajdował się statek lub samolot w momencie, gdy na jego pokładzie zaistniało zdarzenie powodujące szkodę lub powstała szkoda, jest nieprzewidywalne lub nieadekwatne. Wobec obowiązywania szeregu konwencji międzynarodowych dotyczących różnych aspektów odpowiedzialności cywilnej powstającej w związku z ruchem statków lub samolotów ustalenia wymaga ponadto praktyczne znaczenie zasady bandery i zasady państwa rejestracji.

${ }^{1}$ Rozporządzenie nr 1215/2012 z dnia 12 grudnia 2012 r. w sprawie jurysdykcji i uznawania orzeczeń sądowych oraz ich wykonywania w sprawach cywilnych i handlowych (wersja przekształcona), Dz.Urz. UE L 351 z dnia 20 grudnia 2012 r., s. 1-32 ze zm.; dalej: rozporządzenie $\mathrm{nr}$ 1215/2012.

${ }^{2}$ Rozporządzenie nr 864/2007 r. z dnia 11 lipca 2007 r. dotyczące prawa właściwego dla zobowiązań pozaumownych („Rzym II”), Dz.Urz. UE L 199 z dnia 31 lipca 2007 r., s. 40—49; dalej: rozporządzenie $\mathrm{nr} 864 / 2007$. 


\section{2. Źródla norm jurysdykcyinych i norm kolizyjnych dla deliktów w Unii Europejskiej}

Podstawowym aktem prawnym regulującym jurysdykcję krajowa w sprawach cywilnych i handlowych w Unii Europejskiej jest rozporzadzenie nr 1215/2012 ${ }^{3}$. Ustanowione w nim jednolite normy jurysdykcyjne zasadniczo znajdują zastosowanie wtedy, kiedy pozwany, niezależnie od obywatelstwa, ma miejsce zamieszkania w jednym z państw członkowskich ${ }^{4}$. Jurysdykcję ogólną, która zgodnie z art. 4 ust. 1 przysługuje sądom państwa członkowskiego miejsca zamieszkania pozwanego, uzupełnia szereg jurysdykcji przemiennych ${ }^{5}$. Stosownie do art. 7 pkt 2 rozporządzenia nr 11215/2012 w sprawach dotyczących czynów niedozwolonych lub czynów do nich podobnych jurysdykcja przysługuje sądom miejsca, w którym nastąpiło lub może nastąpić zdarzenie wywołujace szkodę. Jak wynika z utrwalonego orzecznictwa Trybunału Sprawiedliwości Unii Europejskiej ${ }^{6}$, pod pojęciem „zdarzenia wywołującego szkodę” kryje się zarówno przyczyna szkody („zdarzenie powodujące szkodę”), jak i skutek (,szkoda”)7. Miarodajna jurysdykcyjnie jest wyłącznie szkoda bezpośrednia rozumiana jako naruszenie dobra lub interesu prawnego ${ }^{8}$.

Kolizyjna problematyka czynów niedozwolonych została uregulowana w rozporządzeniu nr 864/20079. Rozporządzenie to w rozdziale drugim

${ }^{3}$ Zob. więcej na temat jurysdykcji krajowej według rozporządzenia nr 1215/2012 m.in. P. Grzegorczyk: Nowy fundament europejskiego prawa procesowego cywilnego: jurysdykcja krajowa, zawistość sprawy oraz uznawanie $i$ wykonywanie orzeczeń $w$ sprawach cywilnych $i$ handlowych wedtug rozporzadzenia Rady i Parlamentu UE Europejskiego nr 1215/2012 (Bruksela Ia) (część I). „Przegląd Sądowy” 2014, nr 6, s. 19-48; J. Zatorska: Komentarz do rozporzadzenia $n r$ 1215/2012 w sprawie jurysdykcji $i$ uznawania orzeczeń sqdowych oraz ich wykonywania $w$ sprawach cywilnych $i$ handlowych. LEX/el. 2015.

${ }^{4}$ Zob. art. 5 ust. 1 i art. 6 ust. 1 rozporządzenia nr 1215/2012.

${ }^{5}$ Jurysdykcja ogólna i uzupełniające ja jurysdykcje przemienne nie obejmuja spraw, dla których ustanowiono jurysdykcje wyłączne (art. 24), spraw dotyczących ubezpieczenia (art. 10-16), spraw dotyczących umów konsumenckich (art. 17-19) oraz spraw dotyczących indywidualnych umów o pracę (art. 20-23). Strony mogą również stosownie do art. 25 rozporządzenia zawrzeć umowę jurysdykcyjną.

${ }^{6}$ Dalej: TSUE.

${ }^{7}$ Zob. w szczególności wyrok TSUE z dnia 30 listopada 1976 r. w sprawie 21/76 Handelskwekerij G. J. Bier BV przeciwko Mines de potasse d'Alsace SA, ECLI:EU:C:1976:166.

${ }^{8}$ Zob. w szczególności wyrok TSUE z dnia 19 września 1995 r. w sprawie C-364/93 Antonio Marinari przeciwko Lloyds Bank plc i Zubaidi Trading Company, ECLI:EU:C:1995:289.

${ }^{9}$ Zob. więcej na temat rozporządzenia nr 864/2007 np. M. Czepelak: Międzynarodowe prawo zobowiazań Unii Europejskiej. Warszawa 2012; M. Pazdan (red.): System 
zawiera ogólną regulację wskazania prawa właściwego dla czynów niedozwolonych oraz szereg szczegółowych norm kolizyjnych dla wyodrębnionych kategorii czynów niedozwolonych. Wskazanie prawa właściwego dla czynów niedozwolonych nieobjętych jedną ze szczegółowych norm ustanowionych w art. 5-9 rozporządzenia zostało oparte na kaskadzie dwóch łączników. Zgodnie z art. 4 ust. 1 rozporządzenia prawem właściwym dla zobowiązania pozaumownego wynikającego z czynu niedozwolonego jest prawo państwa, w którym powstaje szkoda, niezależnie od tego, w którym państwie miało miejsce zdarzenie ja powodujacce, oraz niezależnie od tego, w którym państwie lub państwach występuja skutki pośrednie tego zdarzenia. Z pierwszeństwem przed łacznikiem lokalnym na zasadzie lex specialis derogat legi generali jest stosowany podmiotowy łacznik wspólnego, w chwili powstania szkody, miejsca zwykłego pobytu osoby, której przypisuje się odpowiedzialność, i poszkodowanego (art. 4 ust. 2). W art. 4 ust. 3 rozporządzenia zamieszczona została klauzula korekcyjna ściślejszego związu. Choć zasadniczo właściwość prawa została powiązana z miejscem powstania szkody, to miejsce zdarzenia ja powodujacego nie zostało zupełnie pozbawione znaczenia. Zgodnie bowiem z art. 17 rozporządzenia nr 864/2007, uwzględnia się, na ile okaże się to wskazane i jako element stanu faktycznego, zasady bezpieczeństwa i postępowania wiążące $\mathrm{w}$ miejscu i czasie wystąpienia zdarzenia stanowiącego źródło odpowiedzialności ${ }^{10}$. Niezależnie od tego w art. 14 rozporządzenia $\mathrm{nr}$ 864/2007 przewidziano możliwość dokonania wyboru prawa właściwego ${ }^{11}$.

Miejsce zdarzenia powodującego szkodę oraz miejsce powstania szkody stanowia podstawy jurysdykcji przemiennej w sprawach dotyczących czynów niedozwolonych. Uzupełniają więc jurysdykcję ogólną sądów państwa członkowskiego, w którym pozwany ma miejsce zamieszkania (art. 4 ust. 1 rozporządzenia $\mathrm{nr}$ 1215/2012). Natomiast w rozporządzeniu nr 864/2007 łącznik miejsca powstania szkody pełni funkcję podstawo-

Prawa Prywatnego, T. 20B. Prawo Prywatne Międzynarodowe. Warszawa 2015, s. 725880; J. Poczobut (red.): Prawo prywatne międzynarodowe. Komentarz. Warszawa 2017 s. 571-601; M. Pazdan (red.): Prawo prywatne międzynarodowe. Komentarz. Warszawa 2018 , s. $877-1034$.

${ }^{10}$ Mimo niezbyt fortunnej redakcji przepisu nie powinno budzić wattpliwości, że chodzi o miejsce zdarzenia powodujaceego szkodę.

${ }^{11}$ Zob. więcej na temat wyboru prawa właściwego dla czynów niedozwolonych M. Czepelak: Wybór prawa wtaściwego dla zobowiazań pozaumownych $w$ rozporzadzeniu rzymskim II. „Kwartalnik Prawa Prywatnego” 2009, z. 2, s. 513-572; M. Czepelak: Autonomia woli w prawie prywatnym międzynarodowym Unii Europejskiej. Warszawa 2015, s. 51-70; J. Pazdan: Wybór prawa wtaściwego, [w:] System Prawa Prywatnego, T. 20B. Prawo Prywatne Międzynarodowe. Red. M. Pazdan. Warszawa 2015, s. $755-760$. 
wego powiązania służącego wskazaniu prawa właściwego (art. 4 ust. 1 rozporządzenia $\mathrm{nr} 864 / 2007)^{12}$, a łącznik miejsca zdarzenia powodujacego szkodę służy identyfikacji miarodajnego wzorca oceny postępowania osoby, której odpowiedzialność cywilna jest rozważana lub ze względu na której działania lub zaniechania jest rozważana odpowiedzialność cywilna innej osoby (art. 17 rozporządzenia nr 864/2007). Mimo że na gruncie jurysdykcyjnym deliktowe łączniki lokalne odgrywają inną rolę niż w prawie kolizyjnym, to nie ma powodów do odmiennego traktowania problemu niemożności, trudności lub nieadekwatności ich zastosowania przy uwzględnieniu władztwa terytorialnego w wypadkach, gdy miarodajne okoliczności zaistniały na pokładzie statku lub samolotu. Normy jurysdykcyjne i normy kolizyjne sa bowiem identycznie zbudowane (w hipotezie podstawowe miejsce zajmuje zakres, natomiast $\mathrm{w}$ dyspozycji znajduje się łącznik oraz odpowiednio wskazanie, że sprawa należy do jurysdykcji krajowej ${ }^{13}$ lub nakaz stosowania określonego prawa). Deliktowe łączniki lokalne pełnia podobną funkcję, pozwalając zidentyfikować państwo, któremu przysługuje deliktowa jurysdykcja przemienna lub którego prawo jest właściwe dla czynu niedozwolonego albo w którym wiążące zasady bezpieczeństwa i zasady postępowania powinny zostać uwzględnione na potrzeby oceny zachowania sprawcy szkody. $\mathrm{Na}$ rzecz łącznego i jednolitego rozstrzygnięcia na płaszczyźnie jurysdykcyjnej i płaszczyźnie kolizyjnej przemawia również okoliczność, że rozporządzenie $\mathrm{nr}$ 1215/2012 oraz rozporządzenie $\mathrm{nr}$ 864/2007 są częścia unijnego prawa prywatnego międzynarodowego, które zgodnie z art. 81 ust. 2 lit. c Traktatu o funkcjonowaniu Unii Europejskiej ${ }^{14}$ obejmuje nie tylko prawo kolizyjne, ale rozciaga się również na międzynarodowe postępowanie cywilne, w tym w szczególności na normy jurysdykcyjne. Ponadto w motywie 7 rozporządzenia nr 864/2007 wyraźnie wskazano, że przedmiotowy zakres zastosowania oraz przepisy tego rozporządzenia

${ }^{12}$ Mimo że łącznik miejsca powstania szkody jest wyprzedzany przez łącznik wspólnego miejsca zwykłego pobytu poszkodowanego i osoby, której przypisuje się odpowiedzialność (art. 4 ust. 2 rozporządzenia nr 864/2007).

${ }^{13}$ Norma jurysdykcyjna, niezależnie od swojej genezy, jest stosowana przez sąd na potrzeby rozstrzygnięcia o jurysdykcji krajowej zawsze jako jednostronna norma kolizyjna. Choć więc art. 7 pkt 2 rozporządzenia nr 1215/2012 przyznaje jurysdykcję sądowi miejsca zdarzenia wywołującego szkodę, to sąd polski będzie badał, czy zdarzenie wywołujące szkodę było zlokalizowane w Polsce (w okręgu sądu, do którego został wniesiony pozew — ze względu na to, że rozporządzenie nr 1215/2012 reguluje w omawianym przypadku nie tylko jurysdykcję krajową, ale również właściwość miejscową).

${ }^{14}$ Dz.U. 2004, nr 90, poz. 864, zał. 2 ze zm.; t.jedn. Dz.Urz. UE C 202 z dnia 7 czerwca 2016 r., s. 47-200; dalej: TFUE. Zob. szerzej na temat tego przepisu A. Wróbel (red.): Traktat o Funkcjonowaniu Unii Europejskiej. Tom I. Warszawa 2012, komentarz do art. 81. 
powinny być spójne z obecnym rozporządzeniem nr 1215/2012 oraz z instrumentami dotyczącymi prawa właściwego dla zobowiązań umownych. O potrzebie spójnej wykładni świadczy również to, że kolizyjny łacznik deliktowy został sformułowany przy uwzględnieniu utrwalonej wykładni jurysdykcyjnego łącznika miejsca zdarzenia wywołujaccego szkodę.

\section{Stosowanie łączników lokalnych}

Lokalne łączniki miejsca zdarzenia powodujaccego szkodę i miejsca powstania szkody odgrywaja kluczową rolę zarówno na gruncie jurysdykcyjnym, jak i na płaszczyźnie kolizyjnej. Rozstrzyganie o jurysdykcji krajowej lub o prawie właściwym za pomoca łączników lokalnych wiąże się z wieloma trudnościami, które ujawniaja się na różnych etapach ich stosowania. W pierwszej kolejności dotyczą one prawidłowej identyfikacji okoliczności, które zostały podniesione do rangi łączników. Niezależnie od tego, że do powstania szkody może prowadzić szereg nadających się do wyodrębnienia aktywności, należy ustalić jedna z nich, która będzie stanowiła zdarzenie powodujace szkodę (zdarzenie sprawcze). Choć zdarzenie sprawcze może pociągać za sobą szereg negatywnych konsekwencji, to prawodawca unijny jurysdykcję krajową i właściwość prawa wiąże wyłącznie ze szkodą bezpośrednią. W następnej kolejności pojawia się potrzeba zlokalizowania w przestrzeni miarodajnych okoliczności stanowiących zdarzenie powodujące szkodę lub szkodę. Jurysdykcja przysługuje bowiem sąom państwa członkowskiego, w którym miało miejsce zdarzenie powodujące szkodę lub w którym powstała szkoda, a właściwe jest prawo państwa miejsca powstania szkody.

Nie znaczy to jednak, że ustalenie, gdzie dokładnie miało miejsce zdarzenie powodujace szkodę lub gdzie powstała szkoda, jest wystarczające. Stosowanie łączników lokalnych opiera się bowiem na niewysłowionym wprost założeniu, że miejsce wskazane przez łącznik opisujący okoliczność lokalną znajduje się pod jurysdykcją terytorialną określonego państwa (państwo sprawuje zwierzchność terytorialną nad miejscem, gdzie wystąpiło zdarzenie powodujące szkodę lub gdzie powstała szkoda). Niektóre obszary nie podlegaja jednak władztwu terytorialnemu żadnego państwa (jak na przykład morze otwarte oraz przestrzeń powietrzna nad nim).

Z niemożnością zastosowania łączników lokalnych w wypadkach, gdy łącznik lokalny znajduje się poza terytorium któregokolwiek pań- 
stwa, ustawodawcy krajowi radzili sobie, odwołując się do zasady bandery (w przypadku statków) lub zasady państwa rejestracji (w przypadku samolotów). Źródeł miarodajności zasady bandery lub zasady państwa rejestracji w prawie prywatnym międzynarodowym należy upatrywać w tym, że na państwie, w którym statek lub samolot został wpisany do odpowiedniego rejestru, ciążą szczególne obowiązki, oraz że temu państwu przysługują szczególe kompetencje w stosunku do osoby mającej określone prawa podmiotowe do tego statku lub samolotu.

\section{Stanowisko prawodawcy unijnego}

Prawodawca unijny ani w rozporządzeniu nr 1215/2012, ani w rozporządzeniu nr 864/2007 nie ustanowił wyraźnej regulacji określającej sposób postępowania w wypadkach, w których stosowanie ustanowionych w nim łączników lokalnych jest niemożliwe, utrudnione albo prowadzi do wattpliwych merytorycznie rezultatów ze względu na przypadkowość lub nieprzewidywalność rozstrzygnięcia opartego na powiązaniu wynikajacym z władztwa terytorialnego nad obszarem, na którym miało miejsce zdarzenie powodujace szkodę lub powstała szkoda.

Problematyka ta nie pozostawała jednak zupełnie poza zainteresowaniem Unii Europejskiej. We wstępnym roboczym projekcie przyszłego rozporządzenia $\mathrm{nr} 864 / 2007^{15}$ znalazła się nawet szczególna norma kolizyjna. Zgodnie z proponowanym art. 4 ust. 1 prawem właściwym dla czynów niedozwolonych, które zaistniały na obszarach niepodlegających władztwu terytorialnemu żadnego państwa, miało być prawo państwa, $\mathrm{w}$ którym środek transportu powiązany z czynem niedozwolonym jest zarejestrowany lub pod którego banderą pływa albo z którym jest w inny podobny sposób związany. W braku powiązania z którymkolwiek państwem lub wtedy, gdy powiązanie zachodziło z kilkoma państwami, prawem właściwym miało być prawo państwa, z którym sprawa pozostawała w najściślejszym związku (art. 4 ust. 2 wstępnego roboczego projektu rozporządzenia).

${ }^{15}$ Preliminary draft proposal for a Council Regulation on the law applicable to non-contractual obligations. Wstępna wersja projektu została opublikowana wraz z komentarzem I propozycją zmian m.in. w „Rabels Zeitschrift für ausländisches und internationales Privatrecht" 2003, z. 1, s. 1-56. 
W ostatecznym projekcie rozporządzenia dotyczącego prawa właściwego dla zobowiązań pozaumownych wniesionym przez Komisję w 2003 r. ${ }^{16}$ zrezygnowano z dyskusyjnego rozwiązania opartego na szczególnej normie kolizyjnej. W zamian zaproponowano normę asymilująca ${ }^{17} \mathrm{~m}$.in. statki i samoloty z terytorium tego państwa, z którym sa one odpowiednio przez podnoszoną banderę lub fakt rejestracji powiązane. Zgodnie z art. 18 projektu za terytorium państwa uznano: a) instalacje i inne wyposażenie służące do badań i eksploatacji surowców naturalnych w, na lub pod częścia dna morskiego położona poza wodami terytorialnymi państwa, jeżeli państwo, na mocy prawa międzynarodowego, korzysta w tej części z suwerennych praw do badań i eksploatacji surowców naturalnych; b) statek na pełnym morzu zarejestrowany w państwie lub posiadajacy certyfikat okrętowy lub porównywalny dokument wydany przez państwo lub w jego imieniu, lub który - nie będąc zarejestrowanym, nie posiadając certyfikatu okrętowego lub porównywalnego dokumentu — jest własnościa obywatela tego państwa; c) samolot w przestrzeni powietrznej zarejestrowany $\mathrm{w}$ państwie lub w jego imieniu, lub wpisany do rejestru państwowego, lub który - nie będac zarejestrowanym lub wpisanym do rejestru państwowego - jest własnością obywatela tego państwa. Ostatecznie przepis ten nie znalazł się w uchwalonym tekście rozporządzenia nr 864/2007.

Braku wyraźniej regulacji nie należy jednak rozumieć w ten sposób, że rozporządzenie $\mathrm{nr}$ 1215/2012 oraz w szczególności rozporządzenie $\mathrm{nr}$ 864/2007 nie znajduja zastosowania w wypadkach, gdy miejsce zdarzenia powodującego szkodę lub miejsce powstania szkody znajduja się na obszarach niepodlegających władztwu żadnego państwa lub też miejsca te trudno jest ustalić. Z milczenia prawodawcy unijnego nie należy też wyciagać wniosku, że rozporządzenia unijne znajduja co prawda zastosowanie, ale stosowanie łączników lokalnych w tych wypadkach jest wyłączone. Na płaszczyźnie jurysdykcyjnej oznaczałoby to, że międzynarodowo właściwe co do zasady byłyby wyłącznie sądy państwa członkowskiego, w którym pozwany ma miejsce zamieszkania (art. 4 ust. 1 rozporządzenia $\mathrm{nr}$ 1215/2012). Na gruncie kolizyjnym zastosowanie mógłby znaleźć łącznik wspólnego miejsca zwykłego pobytu poszkodowanego i osoby, której jest przypisywana odpowiedzialność (art. 4 ust. 2 rozporządzenia $\mathrm{nr}$ 864/2007). W pozostałych przypadkach konieczne byłoby

${ }^{16}$ Proposal for a Regulation of the European Parliament and the Council on the law applicable to non-contractual obligations ("Rome II"), COM(2003) 427 final.

${ }^{17}$ L. Collins i inni (red.): Dicey, Morris \& Collins on the Conflict of Laws, t. II, wyd. 15. London 2012, s. 2215-2216, projektowany art. 18 traktowali jako przepis definiujacy terytorium państwa. 
dokonanie in concreto ustalenia, z którym prawem sprawa jest najściślej związana (art. 4 ust. 3 rozporządzenia nr 864/2007).

Należy również odrzucić interpretację, zgodnie z którą kwestia kolizyjnego znaczenia zasady bandery lub zasady państwa rejestracji pozostaje poza zakresem rozporządzenia nr 1215/2012 oraz rozporządzenia nr 864/2007, w konsekwencji czego rozstrzygając o jurysdykcji lub o prawie właściwym na podstawie łączników lokalnych, sąd polski powinien stosować art. 356 kodeksu morskiego ${ }^{18}$ lub art. 14 prawa lotniczego $^{19}$. Uznanie, że miarodajność zachowuja krajowe uregulowania wobec braku pełnej zgodności stanowisk poszczególnych ustawodawców krajowych, prowadziłoby do niejednolitości zastosowania rozporządzenia $\mathrm{nr}$ 1215/2012 oraz rozporządzenia nr 864/2007, co godziłoby w ich efektywność. Mimo powszechności rozwiązania uwzględniającego zasadę bandery lub zasadę państwa rejestracji, porządki prawne poszczególnych państw członkowskich mogą bowiem różnić się co do tego, czy powiązanie oparte na zasadzie bandery lub na zasadzie państwa rejestracji powinno być miarodajne wyłacznie wtedy, gdy rozstrzygnięcie o jurysdykcji krajowej lub o prawie właściwym na podstawie łączników lokalnych w oparciu o kryterium suwerenności terytorialnej w ogóle nie jest możliwe, czy również wtedy, gdy jest ono utrudnione, lub także wtedy, gdy prowadzi do nieprzewidywalnych lub przypadkowych rezultatów.

Problem określenia, w jakim zakresie zasada bandery i zasada państwa rejestracji moga zostać wykorzystane w celu powiązania zdarzenia mającego miejsce na pokładzie statku lub samolotu z jednym z państw, należy rozstrzygać $\mathrm{w}$ sposób autonomiczny na gruncie unijnego prawa prywatnego międzynarodowego. Brak wyraźnego przepisu nie oznacza więc braku normy. Ciężar zrekonstruowania jej treści jest jednak przeniesiony na judykaturę, która z uwzględnieniem zasad prawa międzynarodowego publicznego ${ }^{20}$ powinna wypracować adekwatne rozwiązania, które jak najlepiej będą odpowiadały systematyce i celom rozporządzenia nr 1215/2012 oraz rozporządzenia nr 864/2007.

${ }^{18}$ Ustawa z dnia 18 września 2001 r. — Kodeks morski, t.jedn. Dz.U. 2018, poz. 2175 ze zm.

${ }^{19}$ Ustawa z dnia 3 lipca 2002 r. - Prawo lotnicze, t.jedn. Dz.U. 2019, poz. 1580.

${ }^{20}$ Jak zauważa A. Dickinson: Territory in the Rome I and Rome II Regulations, [w:] The Hamburg Lectures on Maritime Affairs 2011-2013. Red. J. Bas edow, U. Magnus. Berlin/Heidelberg 2015, s. 85, decyzję o niezamieszczeniu odpowiednich przepisów w rozporządzeniu nr 864/2007 uzasadniono tym, że omawiana kwestia jest raczej domeną prawa międzynarodowego publicznego. 


\section{Terytorium państwa}

W prawie międzynarodowym publicznym przyjmuje się, że terytorium państwowe stanowi przestrzeń, w granicach której państwo wykonuje władzę w sposób wyłączny i pełny w stosunku do osób, zdarzeń i rzeczy ${ }^{21}$. Prawnomiędzynarodowy status mórz jest bardzo zróżnicowany. Artykuł 2 ust. 1 Konwencji o prawie morza ${ }^{22}$ przewiduje, że suwerenność państwa nadbrzeżnego rozciąga się poza jego terytorium lądowe i wody wewnętrzne, a w przypadku państwa archipelagowego poza jego wody archipelagowe, na przyległy pas morza zwany morzem terytorialnym. Zgodnie $\mathrm{z}$ art. 33 ust. 1 konwencji o prawie morza w obszarze strefy przyległej państwo może wykonywać kontrolę konieczną do zapobiegania naruszaniu jego ustaw i innych przepisów celnych, skarbowych, imigracyjnych lub sanitarnych na jego terytorium lub na morzu terytorialnym oraz karania naruszeń takich ustaw i innych przepisów, dokonanych na jego terytorium lub na morzu terytorialnym. Stosownie do art. 56 ust. 1 w wyłącznej strefie ekonomicznej państwo nadbrzeżne ma suwerenne prawa w zakresie badania, eksploatacji i ochrony zasobów naturalnych, zarówno żywych, jak i nieożywionych, wód morskich pokrywających dno, a także dna morskiego i jego podziemia oraz w zakresie gospodarowania tymi zasobami, jak również w zakresie innych przedsięwzięć dotyczących gospodarczego badania i eksploatacji strefy, takich jak wytwarzanie energii poprzez wykorzystanie wody, prądów i wiatrów. Państwu nadbrzeżnemu przysługuje również jurysdykcja w odniesieniu do budowania i wykorzystywania sztucznych wysp, instalacji i konstrukcji; badań naukowych morza; ochrony i zachowania środowiska morskiego. Artykuł 77 konwencji o prawie morza stanowi z kolei, że państwo nadbrzeżne wykonuje suwerenne prawa $\mathrm{w}$ odniesieniu do szelfu kontynentalnego w celu jego badania i eksploatacji jego zasobów naturalnych. Prawa suwerenne państwa nadbrzeżnego nie wpływają jednak na status prawny wód pokrywających szelf ani status przestrzeni powietrznej ponad tymi wodami (art. 78 ust. 1 konwencji).

Artykuł 1 Konwencji o międzynarodowym lotnictwie cywilnym ${ }^{23}$ przewiduje, że każde państwo posiada całkowitą i wyłączną suwerenność w przestrzeni powietrznej nad swoim terytorium. Natomiast art. 2

${ }^{21}$ R. Bierzanek, J. Symonides: Prawo międzynarodowe publiczne, wyd. 7 zmienione. Warszawa 2005, s. 196.

${ }^{22}$ Konwencja Narodów Zjednoczonych, sporządzona w Montego Bay dnia 10 grudnia 1982 r., Dz.U. 2002, nr 59, poz. 543.

${ }^{23}$ Podpisana w Chicago dnia 7 XII 1944 r., Dz.U. 1959, nr 35, poz. 212 zał. ze zm. 
tej konwencji definiuje terytorium państwa jako obszary lądowe i przylegające do nich wody terytorialne, objęte suwerennościa, suzerennościa, mandatem lub opieka tego państwa.

\section{Podstawy miarodajności zasady bandery i zasady państwa rejestracji w prawie prywatnym międzynarodowym}

Normy zwyczajowe prawa międzynarodowego publicznego dotyczące statków morskich zostały skodyfikowane w art. 94 konwencji o prawie morza, który stanowi, że każde państwo skutecznie wykonuje swoja jurysdykcję i kontrolę w dziedzinie administracyjnej, technicznej i socjalnej nad statkami podnoszacymi jego banderę. Statek morski nie powinien jednak być traktowany jako „terytorium pływajace” państwa bandery. W podnoszeniu bandery wyraża się fakt sprawowania przez państwo tzw. zwierzchnictwa okrętowego ${ }^{24}$. Specyficzny status statków morskich został wraz z pojawieniem się lotnictwa przeniesiony również na statki powietrzne. Zgodnie z art. 17 konwencji o międzynarodowym lotnictwie cywilnym statki powietrzne mają przynależność państwowa państwa, w którym są zarejestrowane.

Uwzględniając na gruncie prawa prywatnego międzynarodowego doniosłość zasady bandery lub fakt rejestracji samolotu, ustawodawcy krajowi ustanawiają szczegółowe normy, pozwalające zastosować łączniki lokalne $\mathrm{w}$ oparciu o powiązanie wynikajace z zasady bandery lub z zasady państwa rejestracji. Kodeks morski w art. 356 stanowi, że jeżeli właściwość prawa zależy od miejsca zdarzenia, to za miejsce zdarzenia, które nastąpiło na statku morskim znajdujacym się poza terytorium państwa nadbrzeżnego, uważa się państwo jego bandery. Stosowna regulację przewiduje również prawo lotnicze, które w art. 14 przewiduje, że prawo właściwe dla oceny stosunków cywilnoprawnych powstałych na skutek zdarzenia na statku powietrznym w czasie lotu lub w czasie przebywania na obszarze niepodlegającym zwierzchnictwu żadnego państwa ustala się tak, jak gdyby zdarzenie to nastapiło w miejscu, w którym statek jest zarejestrowany. Przywołane przepisy nie wprowadzają normy kolizyjnej, lecz ustanawiają fikcję, zgodnie z którą okoliczności mające miejsce na pokładzie statku morskiego lub powietrznego należy trakto-

${ }^{24}$ W. Góralczyk, S. Sawicki: Prawo międzynarodowe publiczne w zarysie. Warszawa 2017, s. 214. 
wać tak, jak gdyby zaistniały na terytorium państwa bandery lub państwa rejestracji samolotu.

\section{Zdarzenia na obszarach niepodlegających władztwu terytorialnemu żadnego państwa}

Zgodnie $\mathrm{z}$ dominujacym poglądem $\mathrm{w}$ wypadkach, gdy okoliczności stanowiące zdarzenie powodujące szkodę lub szkoda zaistniały na pokładzie statku lub samolotu znajdującego się na obszarze niepodlegającym władztwu żadnego państwa lub znajdującego się w strefie przyległej albo nad szelfem, ale poza zakresem praw suwerennych państwa nadbrzeżnego, zdarzenie powodujące szkodę lub będącą jego następstwem szkodę należy lokalizować w państwie przynależności statku lub samolo$\mathrm{tu}^{25}$. Prezentowane jest jednak również odmienne zapatrywanie, zgodnie z którym prawo państwa bandery, pod która pływa statek, lub prawo państwa rejestracji samolotu powinno być stosowane nie na podstawie ustanowionego w art. 4 ust. 1 rozporządzenia nr 864/2007 łącznika miejsca powstania szkody przy wykorzystaniu fikcji prawnej nakazującej lokalizować szkodę powstałą na pokładzie statku lub samolotu w państwie bandery lub rejestracji, ale dlatego że w przynależności państwowej stat$\mathrm{ku}$ lub samolotu wyraża się zgodnie $\mathrm{z}$ art. 4 ust. 3 rozporządzenia $\mathrm{nr}$ 864/2007 najściślejszy związek między sprawą a prawem ${ }^{26}$. Ta propozycja opiera się z jednej strony na założeniu, że łączniki lokalne nie znajduja zastosowania wtedy, gdy statek lub samolot znajduje się na obszarze niepodlegającym władztwu żadnego państwa, z drugiej natomiast przyjmuje, że art. 4 ust. 3 rozporządzenia nr 864/2007 nie tylko wprowadza klauzulę ściślejszego związku korygującą wskazanie dokonane za pomoca łącznika opisanego w art. 4 ust. 2 lub 1 rozporządzenia nr 864/2007, ale $\mathrm{w}$ istocie statuuje zapasowy łącznik najściślejszego związku, miaro-

${ }^{25}$ Zob. np. A. Dickinson: The Rome II Regulation: the law applicable to non-contractual obligations. Oxford/New York 2008, s. 324; I. Bach, [w:] Rome II Regulation. Pocket Commentary. Red. P. Huber. Munich 2011, s. 108; J. von Hein, [w:] Rome Regulations. Commentary on the European rules of the conflict of laws. Red. G.-P. Calliess. Alphen aan den Rijn 2011, s. 430; R. Plender, M. Wilderspin: The European Private International Law of Obligations, wyd. 3. London 2009, s. 516; L. Collins i inni (red.): Dicey, Morris \& Collins..., s. 2216; J. Basedow: Rome II at Sea - General Aspects of Maritime Torts. „Rabels Zeitschrift für ausländisches und internationales Privatrecht" 2010, z. 1, s. 133.

${ }^{26}$ I. Bach, [w:] Rome II Regulation..., Red. P. Huber, s. 108. 
dajny w tych wypadkach, w których nie można ustalić prawa właściwego na podstawie art. 4 ust. 1 lub 2 rozporządzenia nr 864/2007.

\section{Zbieg powiązania opartego na władztwie terytorialnym z zasadą bandery lub zasadą państwa rejestracji}

\subsection{Wpływ prawa międzynarodowego publicznego}

Uznanie miarodajności zasady bandery lub państwa rejestracji na potrzeby stosowania łączników lokalnych rodzi pytanie o granice, w jakich zasada bandery lub zasada państwa rejestracji może zostać uwzględniona, w szczególności zaś o to, czy ma ona jedynie subsydiarny charakter czy też może przeważać nad rezultatem zastosowania łączników lokalnych $\mathrm{w}$ oparciu o powiązanie wynikające $\mathrm{z}$ suwerenności państwa nad obszarem, na którym doszło do zdarzenia powodującego szkodę lub w którym powstała szkoda. Przyjęcie pierwszeństwa powiązania wynikającego z zasady bandery lub zasady państwa rejestracji przed powiązaniem opartym na władztwie terytorialnym w żaden sposób nie naruszałoby suwerenności terytorialnej państw ani nie uchybiałoby prawu międzynarodowemu publicznemu. Nie zachodzi bowiem bezpośrednia zależność między stanowiskiem prawa międzynarodowego publicznego co do przedmiotu i granic władztwa terytorialnego a prawem prywatnym międzynarodowym.

Prawo międzynarodowe publiczne, choć uznaje suwerenność państwa nad morzem terytorialnym, to jednocześnie dostrzega jego specyfikę, przewidujacc $\mathrm{w}$ art. 17 konwencji o prawie morza, że z zastrzeżeniem postanowień tej konwencji statki wszystkich państw, zarówno nadbrzeżnych, jak i śródlądowych, korzystaja z prawa nieszkodliwego przepływu przez morze terytorialne. Koresponduje z tym art. 27 ust. 1 tej konwencji, który stanowi, że z wyjątkiem ściśle określonych przypadków państwo nadbrzeżne nie powinno wykonywać jurysdykcji karnej na pokładzie obcego statku przepływającego przez morze terytorialne, w celu aresztowania jakiejś osoby lub przeprowadzenia dochodzenia w zwiąku z jakimkolwiek przestępstwem popełnionym na pokładzie tego statku podczas jego przepływu. Podobnie art. 28 ust. 1 konwencji przewiduje, że państwo nadbrzeżne nie powinno zatrzymywać obcego statku przepływajacego przez morze terytorialne ani zmieniać jego kursu w celu wykonania jurysdykcji cywilnej wobec osoby znajdującej się na pokładzie statku. 
W zakresie jurysdykcji krajowej istnienie zwierzchnictwa terytorialnego nad obszarem, na którym lub nad którym znajdował się statek lub samolot $\mathrm{w}$ chwili wystąpienia zdarzenia powodującego szkodę lub powstania szkody, może co najwyżej przemawiać za tym, żeby państwo, o którego terytorium chodzi, udzieliło ochrony prawnej poprzez ustanowienie jurysdykcji własnych sądów. Państwa samodzielnie wyznaczają granice, w których ich sądy sa powołane do rozpoznawania i rozstrzygania spraw lub dokonywania innych czynności w toczącym się postępowaniu. W praktyce swobodę tę ogranicza dążenie, by sprawa była odpowiednio powiązana $\mathrm{z}$ forum. W granicach wyznaczonych przez zasadę najśsiślejszego związku państwa dysponuja również pewnym marginesem swobody w doborze miarodajnych łączników kolizyjnych.

Przykładu zastosowania powiązania opartego na fakcie rejestracji zamiast równolegle występującego powiązania terytorialnego dostarcza w polskim porządku prawnym art. 14 prawa lotniczego, który prawo właściwe dla oceny stosunków cywilnoprawnych powstałych na skutek zdarzenia na statku powietrznym w czasie lotu każe ustalać tak, jak gdyby zdarzenie to nastąpiło w miejscu, w którym statek jest zarejestrowany, bez różnicowania, czy lot odbywa się nad obszarem podlegającym władztwu terytorialnemu któregoś z państw. Również w art. 18 lit. c projektu rozporządzenia dotyczącego prawa właściwego dla zobowiązań pozaumownych wniesionym przez Komisję w 2003 r. przewidziano asymilację $\mathrm{z}$ państwem rejestracji samolotu znajdującego się $\mathrm{w}$ przestrzeni powietrznej bez wskazania, że chodzi o przestrzeń powietrzną nad obszarami niepodlegajacymi zwierzchnictwu terytorialnemu żadnego państwa, podczas gdy w art. 18 lit. a i b tego projektu. wyraźnie wskazano, że zasada bandery znajduje zastosowanie $\mathrm{w}$ przypadku zdarzeń majacych miejsce poza wodami terytorialnymi lub na morzu otwartym.

Nie ma więc dogmatycznoprawnych przeszkód, by w niektórych odpowiednio uzasadnionych ze względu na generalna potrzebę zapewnienia systemowej spójności prawa międzynarodowego publicznego z prawem prywatnym międzynarodowym — przypadkach miejsce zdarzenia powodującego szkodę i miejsce powstania szkody swoją funkcję lokalizacyjną realizowały nie w stosunku do państwa, które sprawuje suwerenność terytorialna, lecz względem państwa bandery lub państwa rejestracji samolotu. W obu tych ujęciach, jak zauważa M. Sośniak, chodzi o łącznik miejsca deliktu, który jednakże raz jest pojmowany wasko — pokład statku — a raz szeroko — wody terytorialne ${ }^{27}$.

${ }^{27}$ M. Sośniak: Zobowiqzania nie wynikajace z czynności prawnych $w$ prawie prywatnym międzynarodowym. Katowice 1971, s. 117. 


\subsection{Przesłanki i ratio legis pierwszeństwa zasady bandery lub zasady państwa rejestracji}

Uwzględnienie powiązania wynikającego z zasady bandery lub z zasady rejestracji zamiast powiązania opartego na suwerenności terytorialnej można rozważać gdy, kiedy powiąanie wynikające z władztwa terytorialnego jest na tyle słabe, że ustalenie jurysdykcji sądów państwa sprawujacego zwierzchnictwo terytorialne lub zastosowanie jego prawa byłoby przypadkowe i nieprzewidywalne. Inaczej mówiąc, chodzi tu o przypadki, gdy przyznanie jurysdykcji sądom państwa, na którego terytorium zaistniały okoliczności podniesione do rangi łącznika, nie urzeczywistniałoby zasady bliskości sądu i sprawy, a sprawa nie byłaby najściślej związana z obowiązującym w nim prawem. Niejednokrotnie ze względu na szybkość lotu i pułap, na którym poruszają się samoloty, określenie położenia samolotu w momencie, w którym wystąpiły okoliczności podniesione do rangi łączników, może być co najmniej utrudnione ${ }^{28}$. Podobnie J. Basedow odnotowuje, że zasada bandery zwalnia powoda od uciążliwego, a czasami wręcz niemożliwego, dowodu czasu i miejsca popełnienia czynu niedozwolonego (zaistnienia zdarzenia powodującego szkodę lub powstania szkody) ${ }^{29}$. Nie bez znaczenia jest również okoliczność, że osoby znajdujace się na pokładzie statku lub samolotu są zazwyczaj odizolowane od państwa, przez którego terytorium podróżują. Tymczasem rozstrzygnięcie o deliktowej jurysdykcji przemiennej lub o prawie właściwym na podstawie łączników lokalnych poprzez powiązanie nie z państwem, które sprawuje suwerenność nad miejscem zdarzenia lub miejscem powstania szkody, lecz z państwem bandery lub państwem rejestracji, zapewnia generalną przewidywalność wskazania prawa właściwego i deliktowej jurysdykcji przemiennej.

W razie zbiegu powiązania terytorialnego z powiązaniem wynikającym z zasady bandery lub zasady państwa rejestracji należy sięgnąć po to z nich, które in abstracto dla danej klasy przypadków - dzięki czemu zapewniona jest przewidywalność rozstrzygnięć - lepiej realizuje jurysdykcyjną zasadę bliskości sądu i sprawy oraz kolizyjną zasadę najściślejszego związku.

\footnotetext{
${ }^{28}$ Ibidem, s. 124.

${ }^{29}$ J. Bas edow: Rome II at Sea..., s. 133.
} 


\subsection{Pierwszeństwo zasady bandery i zasady państwa rejestracji}

Na tle krajowych norm kolizyjnych M. Sośniak zaproponował, by delikty popełnione na statku znajdującym się na wodach terytorialnych podlegały prawu bandery wtedy, kiedy dotyczą spraw wyłącznie wewnętrznych dla danego statku. Może tu jego zdaniem chodzić o stosunki między członkami załogi lub osobami trwale związanymi ze statkiem. Jeśli natomiast interes państwa przybrzeżnego zostaje $\mathrm{w}$ jakikolwiek sposób naruszony, prawo tego państwa powinno być właściwe ${ }^{30}$. Podobne stanowisko zajął J. Basedow, oceniając, że jeśli deliktowy stan faktyczny zamyka się na pokładzie statku, łączniki lokalne, o ile nie jest możliwe zastosowanie prawa, któremu podlega wcześniejszy stosunek łączący strony, powinny zostać umiejscowione na zasadzie domniemania w państwie bandery. Domniemanie to może zostać jednak obalone w szczególności wtedy, kiedy statek pływa pod tzw. tanią bandera ${ }^{31}$. K. Hertz wyraził z kolei zapatrywanie, że w wypadku gdy szkoda powstaje na pokładzie samolotu lecącego w przestrzeni powietrznej określonego państwa lub statku płynącego po wodach terytorialnych, jurysdykcja przysługuje zarówno sądom państwa, po którego terytorium porusza się statek lub samolot, jak i sądom państwa, pod którego banderą pływa ten statek lub w którym jest zarejestrowany ten samolot ${ }^{32}$.

W wyroku w sprawie C-18/02 ${ }^{33}$ TSUE orzekł, że bandera (fakt rejestracji statku w danym państwie) może być jedynie postrzegana jako jeden z czynników pozwalających zidentyfikować miejsce zdarzenia wywołującego szkodę. W ocenie TSUE przynależność państwowa statku może odegrać decydującą rolę tylko, jeśli sąd krajowy dojdzie do wniosku, że szkoda powstała na jego pokładzie. Choć w piśmiennictwie przywołuje się to rozstrzygnięcie jako potwierdzenie tezy, że zasada bandery jest miarodajna jedynie wtedy, kiedy statek porusza się po morzu otwartym $^{34}$, to w rzeczywistości TSUE w ogóle nie odnosił się do statusu wód,

${ }^{30}$ M. Sośniak: Zobowiazania..., s. $116-117$.

${ }^{31}$ J. Basedow: Rome II at Sea..., s. 132, s. 137.

${ }^{32}$ K. Hertz: Jurisdiction in Contract and Tort under the Brussels Convention. Copenhagen 1998, s. 264.

${ }^{33}$ Wyrok TSUE z dnia 5 lutego 2004 r. w sprawie C-18/02 Danmarks Rederiforening, działajac $w$ imieniu DFDS Torline A/S przeciwko LO Landsorganisationen $i$ Sverige, działajac $w$ imieniu SEKO Sjöfolk Facket för Service och Kommunikation, ECLI:EU:C:2004:74, pkt 44.

${ }^{34}$ P. Mankowski, [w:] Brussels Ibis Regulation. Commentary. Red. U. Magnus, P. Mankowski. Köln 2016, s. 285; I. Bach, [w:] Rome II Regulation... Red. P. Huber, s. 108. Por. również na tle polskiego ustawodawstwa wyrok Sądu Najwyższego z dnia 23 maja 2013 r. w sprawie II CSK 250/12, OSNC 2014, nr 1, poz. 8. 
na których statek znajdował się w momencie powstania szkody, co sugeruje, że okoliczność ta jest bez znaczenia ${ }^{35}$.

Nawet jeśli stan faktyczny zamyka się na pokładzie statku lub samolotu, państwa sa niekiedy zainteresowane tym, co dzieje się na statkach płynących po wodach, nad którymi sprawują zwierzchnictwo terytorialne, lub w samolocie poruszającym się w ich przestrzeni powietrznej. Dotyczy to przede wszystkim państw początku i końca podróży. Państwa te dysponuja i wykonuja jurysdykcję karną oraz administracyjna w najszerszym zakresie. Dotyczy to również państwa przerwy w podróży. Przerwa w podróży niekoniecznie musi mieć planowy charakter. Może zdarzyć się, że w zwiąku z faktem popełnienia czynu niedozwolonego na pokładzie statku lub samolotu państwo, po którego wodach lub w którego przestrzeni powietrznej porusza się ten statek lub samolot, podejmie zgodnie $\mathrm{z}$ prawem międzynarodowym publicznym stosowne czynności, zwłaszcza w ramach jurysdykcji karnej lub administracyjnej, przerywając tym samym podróż. Wtedy, niezależnie od trudności, jakie moga niekiedy wiązać się z ustaleniem, czy zdarzenie sprawcze miało miejsce lub czy szkoda powstała w obszarze podlegającym zwierzchnictwu terytorialnemu państwa początku, końca lub przerwy w podróży, należy przyjąć, że powiązanie wynikające z zasady bandery lub państwa rejestracji ustępuje pierwszeństwa powiązaniu terytorialnemu z państwem początku, końca lub przerwy w podróży. Oznacza to, że w sprawie dotyczacej odszkodowania za szkodę wyrządzoną przez pasażera, który na pokładzie zarejestrowanego w Irlandii samolotu lecącego z Polski do Wielkiej Brytanii tuż po starcie niszczy sprzęt komputerowy należący do innego pasażera, na podstawie art. 7 pkt 2 rozporządzenia nr 1215/2012 międzynarodowo właściwe powinny więc być sądy polskie (sąd miejsca wylotu), a nie sądy irlandzkie.

Podobnie należy ocenić przypadki, gdy do popełnienia czynu niedozwolonego dochodzi w strefie przyległej, wyłącznej strefie ekonomicznej lub na szelfie, jeśli statek lub inny obiekt, na którym doszło do popełnienia czynu niedozwolonego wykonywał czynności mieszczace się $\mathrm{w}$ zakresie, w jakim państwu nadbrzeżnemu przysługuja prawa suwerenne. W wyroku w sprawie C-37/00 ${ }^{36}$ TSUE orzekł, że miejscem świadczenia pracy przez kucharza pracujacego na pokładzie platformy wiertniczej znajdującej się nad szelfem kontynentalnym jest państwo nadbrzeżne. Wniosek ten TSUE oparł w szczególności na okoliczności, że umowa międzynarodowa, której stroną było nadbrzeżne państwo członkowskie,

${ }^{35}$ Podobnie A. Dickinson: The Rome II Regulation..., s. 323.

${ }^{36}$ Wyrok TSUE z dnia 27 lutego 2002 r. w sprawie C-37/00 Herbert Weber przeciwko Universal Ogden Services Ltd., ECLI:EU:C:2002:122. 
przyznaje państwu nadbrzeżnemu suwerenne prawo w zakresie badania i eksploatowania szelfu oraz upoważnia do budowy instalacji podlegających jego jurysdykcji. A contrario jeśli do popełnienia czynu niedozwolonego nie dochodzi w związku lub ze skutkiem dla eksploracji lub eksploatacji zasobów naturalnych szelfu, okoliczność, że łącznik lokalny jest zlokalizowany w obrębie szelfu, nie będzie uzasadniała przyznania jurysdykcji sądom państwa nadbrzeżnego ani przyjęcia właściwości jego prawa $^{37}$.

Powiązanie wynikające $\mathrm{z}$ zasady bandery będzie miało natomiast pierwszeństwo przed powiązaniem terytorialnym wtedy, kiedy statek płynie po wodach podlegających zwierzchnictwu terytorialnemu państwa innego niż państwo początku, końca lub przerwy podróży. Podobnie powiązanie wynikajace z zasady państwa rejestracji wyprzedzi powiąanie terytorialne wtedy, kiedy samolot porusza się w przestrzeni powietrznej państwa innego niż państwo początku, końca lub przerwy podróży. Przeciwko proponowanemu rozwiązaniu mógłby prima facie przemawiać wyrok w sprawie C-51/97, w którym TSUE orzekł, że w przypadku przewozu towarów szkodę należy lokalizować w miejscu, do którego przewoźnik rzeczywiście wykonujący przewóz miał dostarczyć rzeczy. Wydawać by się mogło, że nic nie stało na przeszkodzie, by szkodę zlokalizować w państwie, pod którego banderą statek pływał. Nie ulega bowiem wątpliwości, że szkoda powstała na pokładzie statku. Jednak powiązanie oparte na zasadzie bandery powinno korzystać z pierwszeństwa przed powiązaniem terytorialnym tylko wtedy, kiedy stan faktyczny zamyka się na pokładzie statku, nie majac żadnego związku z państwem, po którego wodach porusza się statek, chyba że jest to państwo początku, końca albo przerwy w podróży. Problemem była jednak niemożność określenia momentu, w którym doszło do powstania szkody. Przewoźnik, który faktycznie wykonywał przewóz, mógł spowodować szkodę najpóźniej w momencie, w którym przewożony towar miał wyjść spod jego władztwa. Jest to też moment, w którym w normalnym toku czynności osoba trzecia, w tym w szczególności poszkodowany, najwcześniej mogła stwierdzić szkodę. Kluczowe znaczenie miał więc moment dostarczenia towaru, a co za tym idzie miarodajne było państwo, do którego przewoźnik faktycznie wykonujący przewóz rzeczywiście dostarczył towar. Wyrządzenie szkody w przewożonym drogą morską towarze tylko przedmiotowo ogranicza się do pokładu statku, podmiotowo natomiast wykracza poza niego, obejmując jako bezpośrednio poszkodowanego osobę, która nie jest obecna na pokładzie. W konsekwencji rozstrzygnięcie TSUE, zgodnie z którym łącznik miejsca powstania szkody powinien być zlokalizowany w państwie,

\footnotetext{
${ }^{37}$ J. Basedow: Rome II at Sea..., s. 130.
} 
do którego przewożony towar miał zostać rzeczywiście dostarczony, a nie w państwie bandery, jest nie tylko trafne, ale daje się ponadto pogodzić z postulowanym wyodrębnieniem przypadków, gdy zdarzenie powodujące szkodę ma miejsce lub szkoda powstaje w państwie początku, końca lub przerwy w podróży. Przyjęta przez TSUE fikcja, że szkoda powstała $\mathrm{w}$ momencie dostarczenia towaru do miejsca docelowego, przemawia za przyznaniem pierwszeństwa powiązaniu terytorialnemu przed powiązaniem opartym na zasadzie bandery.

\section{Zdarzenia wykraczające poza pokład statku lub samolotu}

Jeśli natomiast deliktowy stan faktyczny nie zamyka się na pokładzie statku lub samolotu i obejmuje również państwo, po którego wodach statek płynie lub w którego przestrzeni powietrznej samolot się porusza, miarodajne powinno być powiąanie terytorialne. W sytuacji, gdy pasażer traci życie przez utonięcie po wypadnięciu z pokładu znajdującego się na wodach terytorialnych statku na skutek nieprawidłowo wykonanego manewru skrętu, zarówno zdarzenie, jak i szkoda powinny zostać zlokalizowane w państwie nadbrzeżnym. W wypadku kolizji dwóch samolotów nad terytorium państwa łacznik miejsca powstania szkody zostanie zlokalizowany w państwie, w którego przestrzeni powietrznej doszło do kolizji ${ }^{38}$. Jeśli w trakcie lotu został dokonany zrzut paliwa lub doszło do odpadnięcia części poszycia samolotu lub wypadnięcia przewożonego przez niego ładunku albo doszło do wyrządzenia szkody na powierzchni ziemi lub na wodach objętych suwerennością terytorialną określonego państwa lub innym przysługujacym temu państwu prawem suwerennym i w zakresie tego prawa, miarodajne łączniki lokalne odnoszace się do okoliczności zrzutu, odpadnięcia lub wypadnięcia jako zdarzeń powodujących szkodę oraz do wyrządzenia szkody należy umiejscowić na terytorium tego państwa, w którego przestrzeni powietrznej te okoliczności zaistniały lub na terytorium którego szkoda została wyrządzona ${ }^{39}$. W razie

${ }^{38}$ Tak również L. Collins i inni (red.): Dicey, Morris \& Collins..., s. 2218. W starszym piśmiennictwie E. Rabel: The Conflict of Laws: A Comparative Study, Vol. 2 Foreign Corporations: Torts: Contracts in General, wyd. 2 (przyg. U. Drobnig). Ann Arbor 1960, s. 346.

${ }^{39}$ Polska nie jest stroną konwencji dotyczącej szkód wyrządzonych osobom trzecim na powierzchni ziemi przez obce statki powietrzne, sporządzonej w Rzymie dnia 7 października 1952 r. (Convention on damage caused by foreign aircraft to third parties on the Surface, UN Treaty Series 1958, Vol. 310, No. 4493). 
kolizji statków, do której doszło w porcie lub na wodach wewnętrznych albo morzu terytorialnym, łączniki lokalne wskażą państwo nadbrzeż$\mathrm{ne}^{40}$. Podobnie będzie w odniesieniu do zdarzeń, które miały miejsce w strefie przyległej lub w wyłącznej strefie ekonomicznej, jeśli statek lub platforma, a w razie kolizji przynajmniej jeden ze statków lub platforma wydobywcza, prowadziła działalność mieszczącą w zakresie władztwa państwa nadbrzeżnego ${ }^{41}$.

Jeśli odpowiedzialność za szkodę wynikająca ze śmierci pasażera, do której doszło na skutek jego wypadnięcia za burtę na morzu otwartym, jest przypisywana w związu z nieprawidłowo wykonanym przez załogę statku manewrem, zdarzenie powodujące szkodę należy umiejscowić w państwie, pod którego banderą pływa statek. Niekiedy łącznik miejsca zdarzenia powodujacego szkodę zostanie zlokalizowany w innym miejscu, na przykład w państwie, w którego porcie niewłaściwie przeprowadzono konserwację barierek ochronnych. Ponieważ jurysdykcyjnie i kolizyjnie doniosła jest jedynie szkoda bezpośrednia, w przypadku roszczeń krewnych lub innych osób domagających się naprawienia uszczerbków powstałych po śmierci pasażera miarodajną szkodę należy wiązać z okolicznościami dotyczącymi pasażera, a więc z utratą przez niego życia ${ }^{42}$. Mimo że do utonięcia doszło na morzu otwartym, ze względu na to, że ciąg prowadzących do niego zdarzeń został zainicjowany na pokładzie statku, z którego poszkodowany wypadł, zasadne wydaje się przyjęcie fikcji, że śmierć nastąiła w państwie bandery ${ }^{43}$.

Rozwiązanie polegające na lokalizacji okoliczności stanowiących zdarzenie powodujące szkodę $\mathrm{i}$ szkodę $\mathrm{w}$ państwie bandery opiera się na dwóch założeniach. Po pierwsze przyjmuje, że miarodajne okoliczności zlokalizowane poza pokładem statku (na przykład zatonięcie pasażera) powinny być traktowane tak jak, gdyby wystapiły na pokładzie statku, a po drugie przewiduje, że łacznik lokalny powinien znaleźć zastosowanie za pośrednictwem powiązania opartego na zasadzie bandery.

${ }^{40}$ E. Rabel: The Conflict of Laws..., s. 339; L. Collins i inni (red.): Dicey, Morris \& Collins..., s. 2216; R. Plender, M. Wilderspin: The European Private..., s. 535.

${ }^{41}$ Zob. wyrok Trybunału w sprawie C-37/00. Tak również L. Collins i inni (red.): Dicey, Morris \& Collins..., s. 2216; J. Basedow: Rome II at Sea..., s. 133-134; R. Plender, M. Wilderspin: The European Private..., s. 536.

${ }_{42}$ Zob. wyrok TSUE z dnia 10 grudnia 2015 r. w sprawie C-350/14 Florin Lazar przeciwko Allianz SpA, ECLI:EU:C:2015:802.

${ }^{43} \mathrm{~W}$ sprawie Rundell $v$ La Compagnie Generale Transatlantique, (1900) 100, Fed. 655 , sąd amerykański oddalił roszczenia wynikające ze śmierci pasażera spowodowanej zatonięciem przewożącego go statku, stwierdzając, że pasażer nie został poszkodowany na pokładzie statku, lecz w morzu otwartym, w związku z czym do odpowiedzialności francuskiego przewoźnika nie stosowało się prawo francuskie. Natomiast ogólne powszechne prawo morza nie przyznaje roszczeń w razie śmierci poszkodowanego. 


\section{0. Łączniki lokalne w wypadku kolizji statków lub samolotów}

Wiele wątpliwości budzą również przypadki kolizji statków na morzu otwartym i samolotów w przestrzeni powietrznej nad obszarami niepodlegającymi władztwu terytorialnemu żadnego państwa. Kolizji statków dotyczy konwencja o ujednostajnieniu niektórych przepisów dotyczących zderzeń $^{44}$. Jest ona stosowana wtedy, gdy wszystkie wchodzące w rachubę statki sa przynależne do umawiających się państw (art. 12 ust. 1). Do osób będących obywatelami państw trzecich jej stosowanie może być uzależnione od zasady wzajemności (art. 12 ust. 2 pkt 1). Konwencja nie znajduje natomiast zastosowania do okrętów wojennych oraz do statków państwowych, przeznaczonych wyłącznie do służby publicznej (art. 11).

W przypadkach nieuregulowanych przez prawo jednolite lub poza jego zakresem konieczne jest jednak sięgnięcie do klasycznego mechanizmu kolizyjnego. Nie ma przeszkód, by powiązanie oparte na zasadzie bandery lub na zasadzie państwa rejestracji znalazło zastosowanie również w wypadku kolizji statków pływających pod tą samą bandera lub zderzenia samolotów zarejestrowanych w tym samym państwie. Identyczne zapatrywane wyraził E. Rabel, którego zdaniem w razie kolizji na morzu otwartym dwóch statków płynących pod tą samą banderą właściwe powinno być prawo bandery ${ }^{45}$. Podobnie w ocenie M. Sośniaka właściwość prawa wspólnej bandery nie budzi żadnych zastrzeżeń ${ }^{46}$. M. Dragun-Gertner podstawy do zastosowania prawa wspólnej bandery doszukuje się natomiast w art. 4 ust. 2 rozporządzenia nr 864/2007, oceniając, że przynależność do tego samego państwa wiąże się z tym samym miejscem zwykłego pobytu lub siedzibą podmiotów eksploatujacych takie statki ${ }^{47}$.

$\mathrm{Na}$ gruncie kolizyjnym fakt, że dwa statki podnoszą tę samą banderę lub dwa samoloty zostały wpisane do rejestru w tym samym państwie można alternatywnie rozpatrywać jako okoliczność przesądzająca o istnieniu najściślejszego związku z państwem wspólnej bandery lub wspólnej rejestracji. Artykuł 4 ust. 3 zd. 1 rozporządzenia nr 864/2007 nie tylko bowiem pozwala skorygować wskazanie prawa właściwego dokonane za pomocą łącznika podmiotowego wspólnego miejsca zwykłego pobytu osoby, której przypisuje się odpowiedzialność, i poszkodowane-

${ }_{44}^{4}$ Podpisana w Brukseli dnia 23 września 1910 r., Dz.U. 1938, nr 101, poz. 670.

${ }^{45}$ E. Rabel: The Conflict of Laws..., s. 348.

${ }^{46}$ M. Sośniak: Zobowiazania..., s. 120.

${ }^{47}$ M. Dragun-Gertner: Kolizyjne prawo morskie. „Studia Prawa Prywatnego" 2013, s. 12 . 
go ${ }^{48}$ lub przez łącznik miejsca powstania szkody, ale stanowi również kodyfikację zasady najśsiślejszego związku w tych przypadkach, w których ani łącznik podmiotowy, ani łącznik przedmiotowy nie mogą znaleźć zastosowania. W razie przyjęcia, że wspólna bandera lub rejestracja $\mathrm{w}$ tym samym państwie świadczy jedynie o istnieniu najściślejszego związku, wykluczona byłaby jednak możliwość ustanowienia deliktowej jurysdykcji przemiennej. Na rzecz rozwiązania zakładającego stosowanie łączników lokalnych przemawia również okoliczność, że zwalnia ono z kłopotliwej niekiedy oceny, które prawo powinno być właściwe w stosunku łączącym poszkodowanego pasażera podróżującego pierwszym statkiem z osobą, do której należy drugi statek bioracy udział w kolizji, lub z kapitanem drugiego statku.

Jeśli natomiast statki nie podnoszą tej samej bandery lub samoloty nie sa zarejestrowane $\mathrm{w}$ tym samym państwie, możliwość skorzystania z łączników lokalnych wydaje się wykluczona. Pojawia się w związku z tym pytanie, które prawo powinno być właściwe w wypadku gdy brakuje również łącznika podmiotowego wspólnego miejsca zwykłego pobytu poszkodowanego i osoby, której przypisuje się odpowiedzialność ${ }^{49}$. E. Rabel wśród możliwych rozwiązań wymienia m.in.: prawo bandery bardziej korzystnej dla pozwanego, prawo bandery, pod która pływa statek strony winnej kolizji, ustalanie odpowiedzialności każdej ze stron zgodnie z bandera należącego do niej statku, kumulatywne stosowanie obu praw, prawo forum ${ }^{50}$. Sady angielskie w takich wypadkach stosują ogólne prawo morza, tak jak jest ono rozumiane w Anglii ${ }^{51}$. Zdaniem M. Sośniaka, prawo sądu powinno znaleźć zastosowanie w przypadkach, w których szkoda zostaje wyrządzona na terytorium niepodlegającym zwierzchnictwu żadnego państwa ${ }^{52}$. W piśmiennictwie dotyczacym rozporządzenia nr 864/2007 proponuje się, by szkodę w rozumieniu art. 4 ust. 1 rozporządzenia nr 864/2007 lokalizować w państwie bandery lub

${ }^{48}$ Podnoszenie tej samej bandery nie może zostać utożsamione z istnieniem miejsca zwykłego pobytu w tym samym państwie - państwie bandery. Zasada bandery jest refleksem podejścia lokalnego, ponieważ umożliwia asymilację pokładu statku z terytorium państwa bandery. $\mathrm{Z}$ kolei powiązanie personalne opiera się na założeniu, że czyn niedozwolony będący źródłem stosunku prawnego między stronami mającymi miejsce zwykłego pobytu w tym samym państwie jest najściślej związany z prawem tego pań stwa jak środowiskiem społecznym i normatywnym, w którym odpowiedzialny i poszkodowany na co dzień funkcjonuja.

${ }^{49}$ Niemożność ustanowienia deliktowej jurysdykcji przemiennej nie stanowi dużego problemu ze względu na jurysdykcję ogólną sądów państwa miejsca zamieszkania pozwanego.

${ }^{50}$ E. Rabel: The Conflict of Laws..., s. 349-351.

${ }^{51}$ L. Collins i inni (red.): Dicey, Morris \& Collins..., s. 2216-2217.

${ }^{52}$ M. Sośniak: Zobowiqzania..., s. 95. 
w państwie rejestracji statku, w obrębie którego miała powstać szkoda, której naprawienia domaga się poszkodowany ${ }^{53}$. Natomiast R. Plender i M. Wilderspin oceniaja, że art. 4 ust. 1 rozporządzenia nr 864/2007 może znaleźć zastosowanie tylko gdy, kiedy oba statki mają identyczną przynależność państwowa lub jest jasne, że szkoda została poniesiona wyłącznie na jednym statku a drugi statek ponosi pełną winę. W pozostałych przypadkach ich zdaniem zastosowanie powinno znaleźć prawo, z którym sprawa jest najściślej związana ${ }^{54}$.

Poszukując rozstrzygnięcia omawianego problemu, można również oprzeć się na okoliczności, że na potrzeby stosowania norm jurysdykcyjnych i kolizyjnych o tym, kto jest poszkodowanym, a kto ponosi odpowiedzialność, nie rozstrzygają normy merytoryczne (prawo właściwe zostanie bowiem dopiero wskazane przez miarodajna normę kolizyjna), lecz rola procesowa w koniunkcji z żądaniem pozwu. Jeśli powód domaga się naprawienia wyrządzonej mu - zgodnie z jego twierdzeniami — szkody, to niezależnie od zasadności tego roszczenia, jest osobą poszkodowana. Pozwany jest natomiast tym, komu odpowiedzialność jest przypisywana. Jeśli natomiast powód żąda ustalenia, że nie ponosi odpowiedzialności deliktowej w stosunku do pozwanego, to poszkodowanym jest pozwany, a powód osobą, której odpowiedzialność jest rozważana. Pomijając wątpliwości, jakie moga powstać w wypadku wytoczenia powództwa wzajemnego, choć znaczenia ich nie należy przeceniać ze względu na uniwersalny charakter zasad żeglugi morskiej i żeglugi powietrznej, można, jak się zdaje, przyjać, że szkoda powstaje w państwie bandery lub w państwie rejestracji tego statku lub samolotu, do którego prawa ma lub na którym znajdował się poszkodowany albo należące do niego rzeczy. Łacznik miejsca zdarzenia powodującego szkodę, jeśli odnosi się do działań podjętych na pokładzie drugiego statku lub samolotu, powinien natomiast zostać zlokalizowany w państwie bandery lub w państwie rejestracji tego statku lub samolotu, do którego prawa ma osoba, której odpowiedzialność jest rozważana, lub na pokładzie którego znajdowała się ta osoba.

\section{Konwencyjne jednolite prawo merytoryczne}

Polska jest stroną szeregu konwencji, które ustanawiaja jednolite normy merytoryczne regulujacce odpowiedzialność przewoźników (w tym

${ }^{53}$ L. Collins i inni (red.): Dicey, Morris \& Collins..., s. 2217; A. Dickinson: The Rome II..., s. 323-324.

${ }^{54}$ R. Plender, M. Wilderspin: The European Private..., s. 534-535. 
niekiedy również osób faktycznie wykonujących przewóz). W dziedzinie przewozu lotniczego podstawowe znaczenie ma Konwencja o ujednoliceniu niektórych prawideł dotyczących międzynarodowego przewozu lotniczego ${ }^{55}$, przewozu morskiego dotyczy Konwencja ateńska w sprawie

${ }^{55}$ Sporządzona w Montrealu dnia 28 maja 1999 r., Dz.U. 2007, nr 37, poz. 235 oraz Dz.Urz. UE L 194 z dnia 18 lipca 2001 r., s. 39-49; dalej: konwencja montrealska. Konwencję montrealska dotychczas ratyfikowało ponad 130 państw oraz w zakresie swoich kompetencji ze skutkiem dla państw członkowskich - Unia Europejska. Aktualna lista państw-stron znajduje się pod adresem: https://www.icao.int/secretariat/legal/List\%20 of\%20Parties/Mt199_EN.pdf [dostęp: 1.01.2020 r.] Konwencja weszła w życie w dniu 4 listopada 2003 r., tj. sześćdziesiątego dnia po złożeniu trzydziestego dokumentu dotyczącego ratyfikacji, przyjęcia, zatwierdzenia lub przystąienia (art. 53 ust. 6 konwencji). Polska dokument ratyfikacyjny złożyła w dniu 17 stycznia 2006 r., co zgodnie z art. 53 ust. 7, który przewiduje, że konwencja ma zastosowanie od sześćdziesiątego dnia po dniu złożenia dokumentu dotyczącego ratyfikacji, przyjęcia, zatwierdzenia lub przystąienia, oznacza, że konwencja montrealska zaczęła wiązać Polskę w dniu 18 marca 2006 r. W Dzienniku Ustaw została jednak ogłoszona dopiero w dniu 1 marca 2007 r. Tymczasem zgodnie z art. 91 ust. 1 Konstytucji warunkiem obowiązywania w polskim porządku prawnym konwencji międzynarodowych ratyfikowanych za uprzednią zgodą wyrażona w ustawie jest ich uprzednie ogłoszenie (zob. m.in. wyrok NSA z 29.12.1999 r., I SA/Po 3057/98, (ONSA 2001, nr 1, poz. 34): „obowiązywanie traktatu na gruncie prawa międzynarodowego nie wystarcza do stosowania go przez sąd krajowy. Traktat powinien nie tylko być ratyfikowany, ale i ogłoszony"). Mogłoby to skłaniać do wniosku, że od dnia 18 marca 2006 r. konwencja montrealska wiązała Polskę wyłącznie w płaszczyźnie międzynarodowej w relacji do innych umawiających się państw. Natomiast w stosunkach prywatnoprawnych powinna być stosowana najwcześniej od dnia ogłoszenia jej w Dzienniku Ustaw lub po upływie 14-dniowej vacatio legis (per analogiam art. 88 ust. 3 zd. 1 Konstytucji w zw. z art. 4 ust. 1 ustawy z dnia 20 lipca 2000 r. o ogłaszaniu aktów normatywnych i niektórych innych aktów prawnych (t.jedn. Dz.U. 2019, poz. 1461). Ponieważ jednak materia uregulowana w konwencji montrealskiej częściowo jest objęta zakresem kompetencji Unii Europejskiej, można przyjąć, że do promulgacji doszło już w dniu 1 maja 2004 r. w raz z przystapieniem Polski do Wspólnot Europejskich (obecnie: Unii Europejskiej). Konwencja została bowiem ogłoszona w Dz.Urz. UE w dniu 18 lipca 2001 r. Zob. również na temat spóźnionej promulgacji konwencji międzynarodowych K. Zawada: Europeizacja międzynarodowego prawa zobowiazań umownych. Od konwencji rzymskiej do rozporzadzenia rzymskiego $w$ sprawie prawa właściwego dla zobowiazań umownych. „Przegląd Sądowy” 2010, nr 5, s. 27; P. Mostowik: Promulgatio et vacatio legis jako warunek powszechnego obowiazywania prywatnoprawnych umów międzynarodowych. „Radca Prawny” 2009, nr 1, s. 25-29.

Konwencja montrealska stosownie do art. 55 ma zastapiła (verba legis: „ma pierwszeństwo stosowania”) w zakresie swojego zastosowania Konwencję o ujednostajnieniu niektórych prawideł dotyczacych międzynarodowego przewozu lotniczego, podpisana w Warszawie dnia 12 października 1929 r., Dz.U. 1933, nr 18, poz. 113, oraz przed uzupełniającymi ją konwencjami i zmieniającymi ją protokołami. Polska przystąpiła do: Protokołu zmieniającego konwencję o ujednostajnieniu niektórych prawideł dotyczących międzynarodowego przewozu lotniczego, podpisana w Warszawie dnia 12 października 1929 r., podpisanego w Hadze dnia 28 września 1955 r., Dz.U. 1963, nr 33, poz. 189 zał., oraz do Konwencji uzupełniającej konwencję warszawską, o ujednostajnieniu niektórych 
przewozu morzem pasażerów i ich bagażu ${ }^{56}$. Regulacje konwencyjne sa uzupełniane przez szereg rozporządzeń unijnych ${ }^{57}$. Korzystne z punktu widzenia poszkodowanych rozwiązania przyjęte $\mathrm{w}$ konwencjach międzynarodowych regulujących odpowiedzialność przewoźnika, a niekiedy również osoby faktycznie wykonującej przewóz, oraz rozwinięty system ubezpieczeń odpowiedzialności cywilnej stanowią silną zachętę do tego, by poszkodowani lub ich krewni występowali z roszczeniami przeciwko tym osobom, których odpowiedzialność została uregulowana w wymienionych konwencjach, a więc przeciwko przewoźnikom lub osobom faktycznie wykonujaçcym przewóz. Mimo że co do zasady poszkodowani sa zwiąani umowa przewozu z przewoźnikami, to okoliczność, że chodzi o szkody na osobie (naruszenie zdrowia lub życia) przemawia za deliktową kwalifikacją ich roszczeń.

Normy merytoryczne ustanowione w konwencji montrealskiej i w konwencji ateńskiej mają ograniczony sytuacyjnie zakres zastosowania ${ }^{58}$.

prawideł dotyczących międzynarodowego przewozu lotniczego wykonywanego przez osobę inną niż przewoźnik umowny, sporządzonej w Guadalajarze dnia 18 września 1961 r., Dz.U. 1965, nr 25, poz. 167 zał.

56 Sporządzona w Atenach dnia 13 grudnia 1974 r., Dz.U. 1987, nr 18, poz. 108 zał.; dalej: konwencja ateńska. Konwencja ta została zmieniona przez Protokół do Konwencji ateńskiej w sprawie przewozu morzem pasażerów i ich bagażu, 1974, sporządzony w Londynie dnia 19 listopada 1976 r., Dz.U. 1994, nr 99, poz. 479. Konwencja ateńska zgodnie z art. 24 ust. 2 weszła w życie w dniu 28 kwietnia 1987 r. (w Dzienniku Ustaw została ogłoszona w dniu 23 czerwca 1987 r.), natomiast protokół ją zmieniający stosownie do art. IV ust. 1 - w dniu 30 kwietnia 1987 r. (ogłoszenie w Dzienniku Ustaw nastapiło dopiero w dniu 21 września 1994 r.).

${ }^{57}$ Zob. w szczególności w dziedzinie przewozu lotniczego Rozporządzenie Rady (WE) nr 2027/97 z dnia 9 października 1997 r. w sprawie odpowiedzialności przewoźnika lotniczego z tytułu wypadków lotniczych, Dz.Urz. UE L 285 z dnia 7 października 1997 r., s. 1-3, dalej: rozporządzenie nr 2027/97, oraz Rozporządzenie (WE) nr 889/2002 Parlamentu Europejskiego i Rady z dnia 13 maja 2002 r. zmieniające rozporządzenie Rady (WE) nr 2027/97 w sprawie odpowiedzialności przewoźnika lotniczego z tytułu wypadków lotniczych, Dz.Urz. UE L 140 z dnia 30 maja 2002 r., s. 2-5, natomiast w odniesieniu do przewozu morskiego: Rozporządzenie Parlamentu Europejskiego i Rady (WE) nr 392/2009 z dnia 23 kwietnia 2009 r. w sprawie odpowiedzialności przewoźników pasażerskich na morskich drogach wodnych z tytułu wypadków, Dz. Urz. UE L 131 z dnia 28 maja 2009 r., s. $24-46$ ze zm.

${ }^{58}$ Stosownie do art. 1 ust. 1 i 2 konwencja montrealska znajduje zastosowanie do międzynarodowego przewozu, w którym, zgodnie z umową stron, miejsce rozpoczęcia i miejsce przeznaczenia, niezależnie od tego, czy będzie miała miejsce przerwa w przewozie lub zmiana statku powietrznego czy nie, sa położone na terytorium dwóch państw-stron lub na terytorium jednego tylko państwa-strony, jeżeli w umowie przewidziano lądowanie na terytorium innego państwa nawet niebędącego państwem-strona. Przewóz bez takiego lądowania między dwoma punktami położonymi na terytorium jednego tylko państwa-strony nie jest uważany za przewóz międzynarodowy w rozumieniu konwencji. Natomiast zgodnie z art. 2 ust. 1 konwencja ateńska ma zastosowanie do przewozu 
Takie ograniczone sytuacyjnie konwencyjne prawo jednolite jest najczęściej stosowane jako legis fori ${ }^{59}$. Stosowanie prawa jednolitego jako części prawa państwa sądu, tak jak każdej innej normy merytorycznej forum, niezależnie od jej genezy, musi opierać się na normie prawa prywatnego międzynarodowego. Ponieważ norma ta powinna prowadzić do właściwości prawa sądu zawsze wtedy, kiedy jest spełniony zakres sytuacyjny zastosowania prawa jednolitego ${ }^{60}$, należy przyjąć, że jest to jednostronna

międzynarodowego, jeżeli: statek podnosi banderę państwa-strony konwencji albo jest w nim zarejestrowany lub umowa przewozu została zawarta w państwie-stronie konwencji, lub miejsce wyjazdu albo przeznaczenia, zgodnie z umową przewozu, znajduje się w państwie-stronie konwencji. Określając zakres sytuacyjny zastosowania reżimów odpowiedzialności ustanowionych w omawianych konwencjach, trzeba jednak uwzględnić rozporządzenia unijne. Na przykład art. 3 ust. 1 rozporządzenia nr 2027/97 w brzmieniu ustalonym przez rozporządzenie nr 889/2002, przewiduje, że „odpowiedzialność przewoźnika lotniczego Wspólnoty w odniesieniu do pasażerów i ich bagażu podlega postanowieniom Konwencji montrealskiej określającym tę odpowiedzialność".

Nieco inaczej przedstawia się to w przypadku niegraniczonego sytuacyjnie prawa jednolitego, które wbrew temu, co mogłoby się wydawać, zazwyczaj nie jest stosowane za pośrednictwem jednostronnej normy kolizyjnej pozbawionej łącznika, która w przedmiotowym zakresie prawa jednolitego zawsze prowadziłoby do właściwości prawa forum, lecz w ramach klasycznego mechanizmu kolizyjnego. Wynika to ze specyfiki nieograniczonego sytuacyjnie prawa jednolitego, które prowadzi do całkowitego wyparcia dotychczasowych regulacji krajowych, w miejsce których wchodzi prawo jednolite. Z tego powodu, niezależnie od tego, czy prawo konstytucyjne forum przewiduje bezpośrednia skuteczność konwencji międzynarodowych, konwencje ustanawiające nieograniczone prawo jednolite są najczęściej implementowane do krajowego porządku prawnego z niezbędnymi uzupełnieniami i modyfikacjami. Nieograniczone sytuacyjnie prawo jednolite zbliża się raczej do ustawy modelowej. Nieograniczone prawo jednolite znajduje zastosowanie wtedy, kiedy normy kolizyjne miarodajne dla danego zakresu wskażą jako właściwe prawo forum lub prawo innego umawiającego się państwa. W tym ostatnim wypadku prawo jednolite nie jest stosowane jako lex fori, lecz jako lex causae.

${ }^{59}$ Ograniczone sytuacyjne prawo jednolite może być również stosowane przez sąd państwa członkowskiego, które nie jest stroną ustanawiającej je konwencji, jeśli miarodajna norma kolizyjna zawarta w rozporządzeniu nr 864/2007 wskaże jako właściwe prawo państwa, które jest stroną tej konwencji, i jednocześnie w okolicznościach stanu faktycznego są spełnione przesłanki zastosowania prawa jednolitego jako części prawa właściwego.

${ }^{60}$ Specyficzna pod tym względem jest Konwencja o umowach międzynarodowej sprzedaży towarów, sporządzona w Wiedniu dnia 11 kwietnia 1980 r. (Dz.U. 1997, nr 45, poz. 286), ponieważ niezależnie od bezpośredniego określenia przesłanek zastosowania ustanowionych $\mathrm{w}$ niej przepisów (zgodnie z art. 1 ust. 1 lit. a konwencja ma zastosowanie do umów sprzedaży towarów między stronami mającymi siedziby handlowe w różnych państwach, jeżeli państwa te są umawiającymi się państwami), art. 1 ust. 1 lit. b konwencji przewiduje stosowanie konwencji również wtedy, gdy normy kolizyjne forum jako właściwe wskazuja prawo umawiającego się państwa. W tym ostatnim wypadku konwencja jest stosowana jako część legis causae, zidentyfikowanej za pomocą miarodajnych norm kolizyjnych. 
norma kolizyjna, która do rangi łącznika podnosi te same okoliczności, od których zależy zastosowanie przez sąd umawiającego się państwa prawa jednolitego ${ }^{61}$. Łącznik lub szereg przemiennych łączników wraz $\mathrm{z}$ nakazem stosowania legis fori składają się na dyspozycję tej normy. W jej hipotezie znajduje się natomiast opis sytuacji życiowej odpowiadajacej kwestiom uregulowanym przez merytoryczne postanowienia prawa jednolitego (zakres), a ponadto okoliczności stanowiące bazę faktyczną łacznika lub łaczników (na przykład wymóg, by strony umowy miały siedziby handlowe w różnych państwach, będących stronami konwencji). Hipoteza tej normy jest więc węższa od hipotezy normy kolizyjnej normalnie miarodajnej dla danego zakresu. Przepisy określające zakres sytuacyjny prawa jednolitego stanowią więc nie tylko podstawę wewnątrzsystemowej normy rozstrzygającej kolizję prawa jednolitego z innymi normami merytorycznymi obowiązującymi w forum, ale sa również podstawa jednostronnej międzysystemowej normy kolizyjnej (normy kolizyjnej prawa prywatnego międzynarodowego) prowadzącej do właściwości prawa forum z pominięciem uniwersalnych norm kolizyjnych miarodajnych dla danego zakresu, a tym samym niezależnie od tego, które prawo wskazałyby jako właściwe.

Jednostronna norma kolizyjna jako mechanizm, za pośrednictwem którego jest stosowane prawo jednolite (mechanizm wyjaśniający stosowanie prawa jednolitego jako legis fori), z natury swojej wyprzedza normy kolizyjne normalnie miarodajne dla danego zakresu. Jeśli w stanie faktycznym brak jest łącznika ${ }^{62}$ jednostronnej normy kolizyjnej (a tym samym nie jest spełniony zakres zastosowania prawa jednolitego) zastosowanie znajduje norma kolizyjna miarodajna dla danego zakresu ustanowiona w rozporządzeniu nr 864/2007. Jednostronna norma kolizyjna i norma kolizyjna ustanowiona w rozporządzeniu nr 864/2007 tworzą tym samym specyficzna kaskadę ${ }^{63}$. Konwencyjne prawo jednolite, które jest stosowane jako część legis fori za pośrednictwem niewysłowionych wprost jednostronnych norm kolizyjnych posługujących się w charakterze łączników okolicznościami miarodajnymi dla ustalenia zakresu zastosowania konwencji ustanawiającej prawo jednolite, wypiera więc

${ }^{61}$ Zob. szerzej na temat łącznika jednostronnej normy kolizyjnej A. Mączyński: Wskazanie kilku praw przez norme kolizyjna prawa prywatnego międzynarodowego, [w:] Rozprawy z polskiego i europejskiego prawa prywatnego. Księga pamiatkowa ofiarowana Profesorowi Józefowi Skapskiemu. Red. A. Mączyński, M. Pazdan, A. Szpunar. Kraków 1994, s. 233; M. Czepelak: Umowa międzynarodowa jako źródto prawa prywatnego międzynarodowego. Warszawa 2008, s. 185.

${ }^{62} \mathrm{~W}$ braku zawartych w hipotezie normy kolizyjnej podstaw faktycznych łącznika.

${ }^{63}$ Regulacja będzie częściowo symetryczna. 
w zakresie przez siebie uregulowanym normy kolizyjne ustanowione w rozporządzeniu nr 864/2007.

Obok norm merytorycznych konwencje ustanawiajace jednolite normy odpowiedzialności cywilnej najczęściej jednocześnie zawieraja normy jurysdykcyjne ${ }^{64}$. Te konwencyjne normy jurysdykcyjne korzystaja w zakresie swojego zastosowania z pierwszeństwa zastosowania przed normami ustanowionymi w rozporządzeniu nr 1215/2012 ${ }^{65}$. Podstawy tego pierwszeństwa zależą od tego, czy Unia Europejska jest obok lub z wyłączeniem państw członkowskich stroną danej konwencji międzynarodowej. Jeśli stronami konwencji są wyłącznie państwa członkowskie, pierwszeństwo zastosowania konwencyjnych norm jurysdykcyjnych będzie opierało się na art. 71 rozporządzenia nr 1215/2012. Stosownie do ust. 1 tego przepisu rozporządzenie nr 1215/2012 nie narusza stosowania konwencji, które regulują jurysdykcję, uznawanie lub wykonywanie orzeczeń w sprawach szczególnych. Artykuł 71 ust. 2 lit. a rozporządzenia nr 1215/2012 przewiduje z kolei, że sąd państwa członkowskiego, które jest stroną konwencji dotyczącej spraw szczególnych, może oprzeć swoją jurysdykcję na tej konwencji, i to także wówczas, gdy pozwany ma miejsce zamieszkania na terytorium państwa członkowskiego, które nie jest jej strona. Pierwszeństwo przyznane na podstawie art. 71 ust. 1 rozporza-

${ }^{64}$ Artykuł 33 ust. 1 konwencji montrealskiej przewiduje, że powództwo w sprawie odszkodowania należy wnieść, według wyboru powoda, na terytorium jednego z państw stron bądź do sądu miejsca zamieszkania przewoźnika lub głównej siedziby jego przedsiębiorstwa albo miejsca, gdzie posiada on placówkę, za pośrednictwem której została zawarta umowa, bądź do sądu miejsca przeznaczenia przewozu. Artykuł 33 ust. 2 tej konwencji dodaje, że w odniesieniu do szkody spowodowanej przez śmierć albo uszkodzenie ciała lub rozstrój zdrowia pasażera powództwo można ponadto wnieść na terytorium jednego z państw stron, w którym w czasie wypadku pasażer miał główne i stałe miejsce zamieszkania i do którego lub z którego przewoźnik wykonuje loty bądź własnymi statkami powietrznymi, bądź zgodnie z umową handlowa statkami powietrznymi innego przewoźnika, a w którym przewoźnik prowadzi działalność w zakresie przewozu lotniczego pasażerów, korzystając z pomieszczeń wynajmowanych lub posiadanych przez niego lub przez innego przewoźnika, z którym ma umowę handlowa.

Z kolei art. 17 ust. 1 konwencji ateńskiej stanowi, że powództwo może w zależności od wyboru powoda być wniesione do sądu miejsca stałego pobytu lub głównej siedziby pozwanego albo sądu miejsca wyjazdu lub miejsca przeznaczenia zgodnie z umową przewozu, albo sądu w państwie zamieszkania lub stałego pobytu powoda, jeżeli pozwany ma w tym państwie przedsiębiorstwo i podlega jurysdykcji tego państwa, albo sądu państwa, w którym zawarta została umowa przewozu, jeżeli pozwany ma w tym państwie przedsiębiorstwo i podlega jurysdykcji tego państwa. Natomiast stosownie do ust. 2 tego przepisu po powstaniu wypadku, który spowodował szkodę, strony mogą uzgodnić, że roszczenie o odszkodowanie zostanie wniesione do dowolnego sądu lub będzie poddane arbitrażowi.

${ }^{65}$ Zob. wyrok TSUE z 7 listopada 2019 r. w sprawie C-213/18 Adriano Guaitoli $i$ in. przeciwko easyJet Airline Co. Ltd, ECLI:EU:C:2019:927. 
dzenia przysługuje bez względu na to, czy konwencja dotycząca spraw szczególnych została zawarta przez wszystkie czy też jedynie niektóre państwa członkowskie, i czy jej stronami obok państw członkowskich sa również państwa trzecie ${ }^{66}$. Stosowanie przepisów konwencji nie może jednak naruszać zasad leżących u podstaw współpracy sądowej w sprawach cywilnych i handlowych w ramach Unii, takich jak zasada swobodnego przepływu orzeczeń w sprawach cywilnych i handlowych, przewidywalność sądów właściwych, pewność prawa dla stron postępowania, prawidłowy wymiar sprawiedliwości, maksymalne ograniczenie ryzyka równoległych postępowań oraz wzajemne zaufanie do sprawowania wymiaru sprawiedliwości w ramach Unii ${ }^{67}$.

Jeśli natomiast stroną konwencji jest wyłącznie lub również Unia Europejska (dotyczy to na przykład konwencji montrealskiej), podstaw pierwszeństwa zastosowania ustanowionych w niej norm jurysdykcyjnych należy doszukiwać się raczej w art. 67 niż w art. 71 rozporządzenia $\mathrm{nr}$ 1215/2012. Artykuł 67 stanowi bowiem, że rozporządzenie $\mathrm{nr}$ 1215/2012 nie narusza stosowania przepisów, które reguluja jurysdykcję lub uznawanie i wykonywanie orzeczeń w sprawach szczególnych i które zawarte sa w unijnych aktach prawnych lub w prawie poszczególnych państw członkowskich, zharmonizowanym poprzez wykonanie takich aktów. Co prawda konwencja międzynarodowa nie jest unijnym aktem prawnym, ale okoliczność ta nie powinna stać na przeszkodzie rozszerzajacej wykładni tego przepisu w szczególności z tego powodu, że w obu przypadkach — zarówno wtedy, kiedy Unia Europejska przyjmuje dyrektywę lub rozporządzenie, jak i wtedy, kiedy przystępuje do konwencji - chodzi o wykonywanie, choć w inny sposób, kompetencji przez Unię Europejska. Ponadto każdorazowo zatwierdzenie konwencji międzynarodowej przez Unię Europejską jest poprzedzone odpowiednim aktem prawnym - decyzją Rady ${ }^{68}$.

${ }^{66}$ Por. na tle art. 71 Rozporządzenie Rady (WE) nr 44/2001 z dnia 22 grudnia 2000 r. w sprawie jurysdykcji i uznawania orzeczeń sądowych oraz ich wykonywania w sprawach cywilnych i handlowych, Dz.Urz. UE L 12 z dnia 16 stycznia 2001 r., s. 1-23 ze zm.; dalej: rozporządzenie nr 44/2001, wyrok TSUE z 14 lipca 2016 r. w sprawie C-230/15 Brite Strike Technologies Inc. przeciwko Brite Strike Technologies SA, ECLI:EU:C:2016:560, pkt. $49-50$.

${ }^{67}$ Por. na tle art. 71 rozporządzenia nr 44/2001, wyrok TSUE z 4 maja $2010 \mathrm{r}$. w sprawie C-533/08 TNT Express Nederland BV przeciwko AXA Versicherung AG, ECLI:EU:C:2010:243, pkt 49. Zob. więcej na ten temat P. Grzegorczyk, P. Rylski, K. Weitz: Przeglad orzecznictwa Europejskiego Trybunału Sprawiedliwości z zakresu europejskiego prawa procesowego cywilnego (2009-2010). „Kwartalnik Prawa Prywatnego" 2011 , z. 3, s. $779-781$.

${ }^{68}$ Zob. art. 218 ust. 2 TFUE. 
Z tych powodów w międzynarodowym przewozie lotniczym i w międzynarodowym przewozie morskim znaczenie deliktowych łączników lokalnych, a tym samym potrzeba ustalenia, czy miarodajne powinno być powiązanie uwzględniające suwerenność terytorialną czy też powiązanie opierające się na zasadzie bandery lub na zasadzie państwa rejestracji, w praktyce jest istotnie ograniczone, zarówno jeśli chodzi o jurysdykcję krajowa, jak i o wskazanie prawa właściwego.

\section{Zakończenie}

Stosowanie deliktowych łączników lokalnych ustanowionych w rozporządzeniu nr 1215/2012 (art. 7 pkt 2) oraz w rozporządzeniu nr 864/2007 (w szczególności art. 4 ust. 1) wymaga nie tylko identyfikacji okoliczności stanowiacych zdarzenie powodujace szkodę lub szkodę oraz ich umiejscowienia, ale również powiązania miejsca zdarzenia powodującego szkodę lub miejsca powstania szkody z konkretnym państwem, którego sądom będzie przysługiwała jurysdykcja (miejscowo właściwy będzie sąd, w którego okręgu miało miejsce zdarzenie powodujące szkodę lub powstała szkoda) lub którego prawo będzie właściwe. Zasadniczo identyfikacji tego państwa dokonuje się w oparciu o zasadę suwerenności terytorialnej. Tradycyjnie w razie niemożności zastosowania zasady terytorialnej z tego powodu, że miarodajna okoliczność wystapiła, gdy statek lub samolot znajdował na obszarze niepodlegającym władztwu żadnego państwa, sięgano po powiązanie wynikajace $\mathrm{z}$ zasady bandery lub z zasady państwa rejestracji.

Mimo że prawodawca unijny ani w rozporządzeniu nr 1215/2012, ani w rozporządzeniu nr 864/2007 nie ustanowił żadnych wyraźnych przepisów dotyczących stosowania deliktowych łączników lokalnych w omawianych wypadkach, nie powinno budzić wattpliwości, że kwestia miarodajności zasady bandery i zasady państwa rejestracji powinna być autonomicznie rozstrzygana przy uwzględnieniu zasad prawa międzynarodowego publicznego, rozważań prawnoporównawczych oraz systematyki i celów tych rozporządzeń.

Jeśli deliktowy łącznik lokalny nie może znaleźć zastosowania z tego powodu, że miarodajne zdarzenie ma miejsce na pokładzie statku poruszającego się po morzu otwartym lub na pokładzie samolotu poruszającego się $\mathrm{w}$ przestrzeni powietrznej nad obszarem niepodlegającym władztwu terytorialnemu żadnego państwa, z pomocą przychodzi zasada 
bandery lub zasada państwa rejestracji, która umożliwia zlokalizowanie zdarzenia powodującego szkodę lub szkody w państwie, pod którego bandera pływa statek lub w którym samolot jest zarejestrowany. Zasada bandery lub zasada państwa rejestracji ma jednak nie tylko subsydiarny charakter, ale niekiedy również wyprzedza powiązanie oparte na władztwie terytorialnym. Dotyczy to tych sytuacji, w których zdarzenie powodujące szkodę lub szkoda mają miejsce na pokładzie statku lub samolotu, który znajduje się na obszarze podlegajacym władztwu terytorialnemu innego państwa niż państwo początku, końca lub przerwy w podróży, do której doszło w związku z podjęciem przez państwo czynności w ramach jurysdykcji karnej lub administracyjnej. Powiąanie terytorialne znajdzie natomiast zastosowanie wtedy, kiedy chodzi o państwo początku, końca lub przerwy podróży, w tym w szczególności przerwy wynikającej z podjęcia działań w reakcji na popełniony czyn niedozwolony. Podobnie należy ocenić te przypadki, gdy deliktowy stan faktyczny nie zamyka się na pokładzie statku lub samolotu i obejmuje również państwo, po którego wodach statek płynie lub w którego przestrzeni powietrznej samolot się porusza.

W wypadku zderzeń statków lub samolotów mających miejsce na obszarach niepodlegajacych władztwu żadnego państwa, łączniki lokalne moga być stosowane nie tylko wtedy, gdy oba statki lub samoloty sa zarejestrowane w tym samym państwie. Wystarczy bowiem szkodę lokalizować $\mathrm{w}$ państwie bandery tego statku lub w państwie rejestracji tego samolotu, z którym związana jest szkoda, którą miał ponieść powód lub pozwany $\mathrm{w}$ wypadku powództw inicjowanych przez potencjalnie odpowiedzialnego. Konsekwentnie zdarzenie powodujące szkodę należy lokalizować $\mathrm{w}$ państwie bandery statku lub rejestracji samolotu, z którego ruchem związane miało być wyrządzenie szkody.

W przypadku przewozu osób znaczenie zabiegu polegającego na posłużeniu się powiązaniem opartym na zasadzie bandery lub na zasadzie państwa rejestracji jest ograniczone ze względu na obowiązywanie konwencji montrealskiej i konwencji ateńskiej, które ustanawiają nie tylko jednolite normy merytoryczne, stosowane z pominięciem norm kolizyjnych ustanowionych $\mathrm{w}$ rozporządzeniu $\mathrm{nr}$ 864/2007, ale zawierają również szczegółowe normy jurysdykcyjne wypierajace zastosowanie rozporządzenia nr 1215/2012, w tym w szczególności art. 7 pkt 2. 